\title{
Circulating H5N1 Virus among Native Chicken Living around Commercial Layer Farms
}

\author{
Tarigan $\mathrm{S}^{1}$, Indriani $\mathrm{R}^{1}$, Ignjatovic $\mathrm{J}^{2}$ \\ ${ }^{1}$ Indonesian Research Centre for Veterinary Science, Jl. RE. Martadinata 30 Bogor, Indonesia 16114 \\ ${ }^{2}$ School of Veterinary and Agricultural Sciences, University of Melbourne, Melbourne, Australia \\ E-mail: simsont@me.com
}

(received 31-07-2015; revised 27-08-2015; accepted 14-09-2015)

\begin{abstract}
ABSTRAK
Tarigan S, Indriani R, Ignjatovic J. 2015. Peredaran virus H5N1 pada ayam buras di sekitar peternakan ayam petelur komersial. JITV 20(3): 224-232. DOI: http://dx.doi.org/10.14334/jitv.v20i3.1190

Sejak diterapkannya program vaksinasi kasus penyakit avian influenza (AI) H5N1 pada ayam pembibitan dan ayam ras petelur jarang terdengar. Penelitian in bertujuan menganalisis apakah redanya kasus tersebut berhubungan dengan hilangnya sumber infeksi di sekitar peternakan. Sampel serum dikumpulkan dari 421 ayam buras yang tinggal di sekitar peternakan ayam petelur di Kabupaten Cianjur dan Sukabumi, Jawa Barat pada Maret-April 2014. Antibodi virus AI H5N1 dianalisis dengan uji haemagglutination ihibition (HI), ELISA dan immunoblotting untuk mendeteksi antibodi terhadap haemagglutin virus H5N1, domain eksternal protein M2 (M2E) dan nukleoprotein (NP) virus AI. Sebanyak 8,6\% dari ayam buras yang diperiksa seropositif terhadap virus AI berdasarkan satu atau lebih dari uji serologis. Hasil penelitian mengungkapkan bahwa virus H5N1 masih beredar pada ayam buras yang berkeliaran disekitar kandang ayam ras petelur. Sera yang positif dengan uji HI, M2E dan NP ELISA berturut turut $2,4 \%, 3,3 \%$ dan 3,8\%. Tidak terlihat kesesuaian antara hasil satu uji dengan uji lainya. Penyebab ketidaksesuaian hasil tersebut diduga karena HI test, MM2e ELISA dan NP ELISA mengukur antibody yang berbeda yang kemunculan dan durasi masing masing antibodi tersebut berbeda. Kenyataan bahwa virus H5N1 masih beredar di sekitar peternakan ayam petelur menunjukkan bahwa ancaman virus AI masih membayangi peternakan ayam komersial dan karena itu vaksinasi dan biosekuriti yang ketat masih dibutuhkan.
\end{abstract}

Kata Kunci: H5N1, Ayam Buras, Petelur Komersial, Nucleoprotein, M2e, Uji HI

\begin{abstract}
Tarigan S, Indriani R, Ignjatovic J. 2015. Circulating H5N1 virus among native chicken living around commercial layer farms. JITV 20(3): 224-232. DOI: http://dx.doi.org/10.14334/jitv.v20i3.1190

Soon after the application of vaccination programme against high pathogenic avian influenza H5N1 outbreak of the disease in breeder and commercial layer farms has diminished remarkably in West Java. This study aimed to investigate whether the $\mathrm{H} 5 \mathrm{~N} 1$ decline is related to the disappearance of source of infection around the farms. Serum samples were collected from 421 native chicken living around commercial layer farms in the Districs of Cianajur and Sukabumi, West Java in March-April 2014. Antibodies to avian influenza virus (AIV) H5N1 were measured using haemaglutination inhibition (HI), ELISAs and immunoblotting that measured presence of antibodies to the haemagglutin of $\mathrm{H} 5 \mathrm{~N} 1$ strain, as well as the M2e and nucleoprotein (NP) of all avian influenza viruses. Based on the combined results, $8.6 \%$ of the native chickens were seropositive to AI virus based on one or more of serological tests. This study provided serological evidence that H5N1 virus was still circulating among native chicken living around commercial layer farms. Many positive sera were however positive for antibodies in one test only: $2.4 \%, 3.3 \%$ and $3.8 \%$ by HI test, M2e and NP ELISA, respectively. It could be speculated that the incongruity of the results is due to the fact that HI, MM2e ELISA and NP ELISA all measure different type of antibodies and the duration of these antibodies in serum following infection with $\mathrm{H} 5 \mathrm{~N} 1$ differ. The fact that $\mathrm{H} 5 \mathrm{~N} 1$ virus is still circulating around commercial layer farms infers that the commercial farms are still under threat and therefore vaccination and strict biosecurity are still needed.
\end{abstract}

Key Words: H5N1, Native Chicken, Commercial Layer, Nucleoprotein, M2e, HI Test

\section{INTRODUCTION}

Indonesia is one of the countries hit hardest by the $\mathrm{H} 5 \mathrm{~N} 1$ virus. In no less than three years after its official declaration in 2004, the disease caused economic losses to the poultry industry of no less than 4.1 trillion rupiahs (Komnas Flu Burung, Antara 24 Maret 2008).
Human deaths caused by the virus have been the highest in Indonesia totaling 165 deaths of 447 globally (www.who.int/influenza/ download July 2015).

Since its first appearance in Indonesia in 2003, HPAI H5N1 spread rapidly leaving little options for the government except to implement mass vaccination. It was decided that vaccination in sector 1,2 , and 3 
commercial poultry was the responsibility of the farm's owners, whereas the sector 4 poultry became the responsibility of the government. To date vaccination of commercial poultry has been successfully applied with vaccination coverage of nearly $100 \%$. As a result, H5N1 outbreaks in sectors 1,2 and 3 have dropped remarkably (Siregar et al. 2007). In sector 4 poultry, on the other hand, mass vaccination was discontinued because of the difficulty in its implementation (Siregar et al. 2007). Due to the lack of control measures, it is suspected that $\mathrm{H} 5 \mathrm{~N} 1$ virus readily spread among poultry in sector 4 , which have become latent treat to the nearby commercial poultry.

Vaccination against influenza virus can protect chickens from mortality and clinical disease but not always against infection (Suarez 2005). This means that if vaccinated commercial poultry are challenged by $\mathrm{H} 5 \mathrm{~N} 1$ originating from surrounding sector 4 poultry, subclinical infection is the most likely outcome. We have investigated this possibility by carrying out a longitudinal study in commercial layer farms in West Java and Jogjakarta provinces. Extensive year-long investigation showed that there was no indication of H5N1 infection on the studied farms. One possible cause for the absence of infection in those layer farms is the absence of virus challenge and by extension also, the absence of infection in native chickens living around farms. This study, which was carried out at the end of our longitudinal study, aims at investigating serologically evidence for the existence of AI virus infection in village, free range or native chickens living in villages around commercial layer farms. The study indicated that $\mathrm{H} 5 \mathrm{~N} 1$ infection was still occurring among many native chickens living around commercial layer farms albeit at low prevalence.

\section{MATERIALS AND METHODS}

\section{Native chickens}

Native chickens living within about $1 \mathrm{~km}$ radius from six commercial layer farms ( 3 farms in Sukabumi and 3 in Cianjur districs) were bled in March - April 2014. The sample collection was facilitated by the officers of District Animal Health Services who organized and asked the village farmers not to release their chicken at the days of sample collection. A simple questionnaire was prepared to ease recording on (1) the age group of each bird bled, (2) the name and address of the owner, (3) number of poultry they owned, (4) if disease or death in poultry had occurred in the neighborhood, (5) whether they vaccinated their chicken against avian influenza, (6) if any of their family or neighborhood worked on commercial layer farms and (7) whether they bought culled chickens from any layer farms.

\section{Serological testing}

Antibodies to AI virus in collected sera were used as an indication of infection by virus, and thus indirectly of the presence of AI virus the population. Initially, three serological tests were used. (1) A non-commercial validated competitive nucleoprotein of type A influenza viruses, irrespective of subtype. Testing was carried out according to the protocol provided by the test developer (AAHL, Australia) with a cut-off value of $\geq 60 \%$ inhibition as suggested. (2) The haemagglutinin inhibition (HI) test, performed according to a standard protocol (OIE 2014) was used to detect antibody to the haemagglutinin specific for the H5 subtype, with a cutoff value for positivity of $4 \log 2$. The HA antigen for the $\mathrm{HI}$ test was prepared from a local isolate A/Ck/WJ/PWT-WIJ/2006 (H5N1). (3) A MAP-M2e ELISA was used to detect antibody to external domain of M2 protein (M2e) of AI (H5N1) virus. The protocols for this test has been described previously (Tarigan et al. 2015). Briefly, diluted sera were added to the 96well microtitre plate that previously had been coated with with 4-symmetry-branched-M2e peptide. Antibody specifically bound to the M2e peptide was probed with HRP-anti-chicken conjugate. The cut-off value for a positive sample was 0.1

Serum samples that were positive with any of the three tests were further analysed with immunoblot or ELISA using relevant recombinant proteins of influenza virus. The recombinant proteins expressed in mammalian cells were obtained from Sino Biologicals Inc. China. The recombinant proteins included full size, polyhistidine-tagged nucleoprotein from Influenza A H1N1 strain (A/Puerto Rico/8/34/Mount Sinai) (cat. no. $11675-\mathrm{V} 08 \mathrm{~B}$ ) and polyhistidine-tagged extradomain of heamagglutinin from Influenza A H5N1 (A/Indonesia/5/2005) GenBank Accession no. ABW06108.1) (Met 1 - Gln 531) with cleavage site mutated (RESRRKKR to obtain noncleaved $\mathrm{H} 1+\mathrm{H} 2$ ) (cat. no. 11060-V08H1).

\section{Indirect NP and H5 ELISAs}

Each recombinant protein was diluted in $0.1 M$ carbonate buffer ( $\mathrm{pH} 9.6$ ) at $2 \mu \mathrm{g} / \mathrm{ml}$ then used to coat microtitre plates (Nunc maxisorp) overnight at $4{ }^{\circ} \mathrm{C}$. After blocking with non-fat-skimmed milk $(5 \mathrm{mg} / \mathrm{ml}, 2$ hrs), serum samples and controls, diluted in PBST (PBS $\mathrm{pH} 7.2,0.05 \%$ Tween-20) at 1:100, or serially diluted when indicated, were added and incubated at $37^{\circ} \mathrm{C}$ for 1 hr. Serum controls included serum from influenza-free chicken (negative control) and serum from chicken that had been vaccinated and infected with a H5N1 virus (A/chicken/West Java/Sbg-29/2007 (GenBank accession no. KC831453.1)) (positive control). After washing 4 times with PBST, anti-chicken-IgG-HRP 
conjugate (Sigma Co. Singapore) diluted at 1:4000 was added then incubated at $37^{\circ} \mathrm{C}$ for $1 \mathrm{hr}$. After washing 4 times, chromogenic (ABTS) substrate was added and the absorbance was recorded with a microtitre-plate reader. The OD of a sample was standardized with the following formula: (OD sample-OD negative control)/(OD positive control - OD negative control). The cut-off value was 0.1 for both indirect NP and H5 ELISAs.

\section{Immunoblotting}

Recombinant proteins diluted at $50 \mu \mathrm{g} / \mathrm{ml}$ in sample buffer, were separated in the $10 \%$-acrylamideseparating gels on SDS PAGE. Proteins from the gels were transferred onto a nitrocellulose membrane. After blocking with skimmed milk ( $5 \mathrm{mg} / \mathrm{ml}, 2 \mathrm{hrs})$, serum samples and controls diluted at 1:200 in PBST, were added and incubated at $25^{\circ} \mathrm{C}$ for $2 \mathrm{hr}$. After washing 4 times with PBST, anti-chicken-IgG-HRP conjugate (Sigma Co. Singapore) diluted at 1:4000 was added then incubated at $25^{\circ} \mathrm{C}$ for $2 \mathrm{hrs}$. After washing 4 times, chromogenic (DAB) substrate was added to probe bound antibody.

\section{RESULTS AND DISCUSSION}

The number of sera available for this study was collected from 421 native chickens ( $40 \%$ growing birds (2-6 months old) and $60 \%$ adult ( $>6$ months) from 16 villages, around 6 layer farms, within a distance of $\approx 1$ $\mathrm{km}$ from the farms (Table 1). They were typically backyard chickens that were free to roam in the neighborhood and around the layer farms during the day. Some owners of native chicken or their neighbors worked on the layer farms and occasionally brought home culled chickens from layer farms and raised them together with their native chickens. However, non of these birds were bled.

Some chickens could not be bled because they had been freed by the owner before the survey teams arrived, and chicks less than 2 months old were not bled. Although the exact number of native chickens around the layer farms were unknown, it was estimated that at least $25 \%$ of the total population was successfully bled.

Thirty six $(8.6 \%)$ of the samples were positive in one or more of the three tests, AAHL-NP ELISA, M2e

Table 1. The number and location of native chickens bleed for the serological surveillance

\begin{tabular}{|c|c|c|c|c|}
\hline \multirow{2}{*}{ District } & \multirow{2}{*}{ Related farm } & \multirow{2}{*}{ Village } & \multicolumn{2}{|c|}{ No. chicken } \\
\hline & & & Village & Farm \\
\hline \multirow{7}{*}{ Cianjur } & \multirow{2}{*}{ 1. CCA* } & 1. Legok Karso & 61 & \multirow{2}{*}{96} \\
\hline & & 2. Ciherang & 35 & \\
\hline & 2. $\mathrm{n} / \mathrm{a}^{\#}$ & 3. Ciremis & 11 & 11 \\
\hline & \multirow{2}{*}{ 3. CKR } & 4. Cinangka & 57 & \multirow{2}{*}{84} \\
\hline & & 5. Bedahan & 27 & \\
\hline & \multirow{2}{*}{ 4. CHA } & 6. Karang Anyer & 42 & \multirow{2}{*}{52} \\
\hline & & 7. Cipolong & 10 & \\
\hline \multirow{9}{*}{ Sukabumi } & \multirow{2}{*}{ 5. STA } & 8. Tangkil Waru & 18 & \multirow{2}{*}{32} \\
\hline & & 9. Tangkil Lande & 14 & \\
\hline & \multirow{4}{*}{ 6. SCR } & 10. Sasagara & 21 & \multirow{4}{*}{97} \\
\hline & & 11. Cikaung & 7 & \\
\hline & & 12. Cikaret hilir & 10 & \\
\hline & & 13. Cibaringbing & 59 & \\
\hline & \multirow{2}{*}{ 7. SPU } & 14. Purwasari & 17 & \multirow{2}{*}{45} \\
\hline & & 15. Sirnabakti & 28 & \\
\hline & 8. $\mathrm{n} / \mathrm{a}$ & 16. Tapos & 4 & 4 \\
\hline \multicolumn{2}{|l|}{ Total } & & 421 & 421 \\
\hline
\end{tabular}

$\left(^{*}\right)$ anonymised name; $\left(^{\#}\right)$ indicates that the sampling was not related to any layer farm. These two villages were sampled because a HPAI outbreak in ducks was reported to have occurred within them 
Tarigan et al. Circulating H5N1 virus among native chicken living around commercial layer farms

Table 2. Results of the examination of sera from native chicken with AAHL NP ELISA, MM2e ELISA and HI test

\begin{tabular}{lcc}
\hline \hline Test & Positive & Negative \\
\hline MM2e ELISA & $14(3.3 \%)$ & $405(96.7 \%$ \\
NP-ELISA & $16(3.8 \%)$ & $403(96.2 \%)$ \\
HI test & $10(2.4 \%)$ & $409(97.6 \%)$ \\
M2e and HI and NP-ELISA & $0(0.0 \%)$ & $419(100.0 \%)$ \\
M2e or HI or NP-ELISA & $36(8.6 \%)$ & $383(91.4 \%)$ \\
M2e and HI & $0(0.0 \%)$ & $419(100.0 \%)$ \\
M2e and NP-ELISA & $1(0.2 \%)$ & $418(99.8 \%)$ \\
HI and NP ELISA & $3(0.7 \%)$ & $416(99.3 \%)$ \\
\hline
\end{tabular}

B

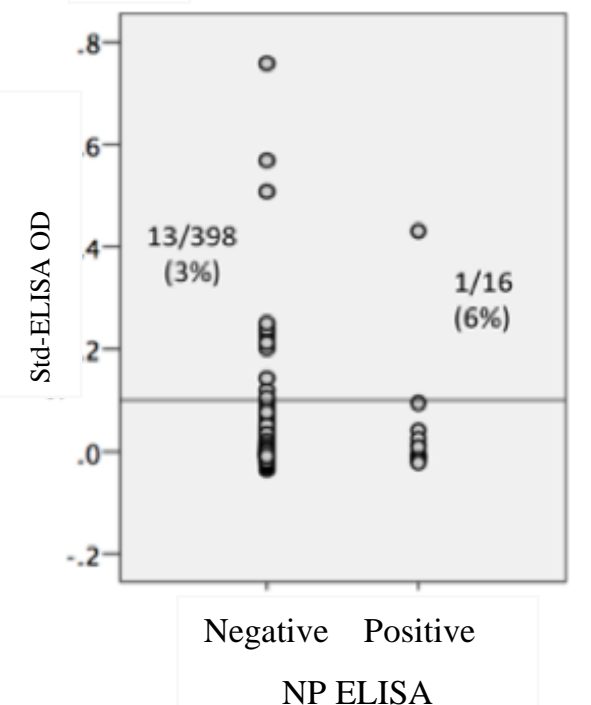

A

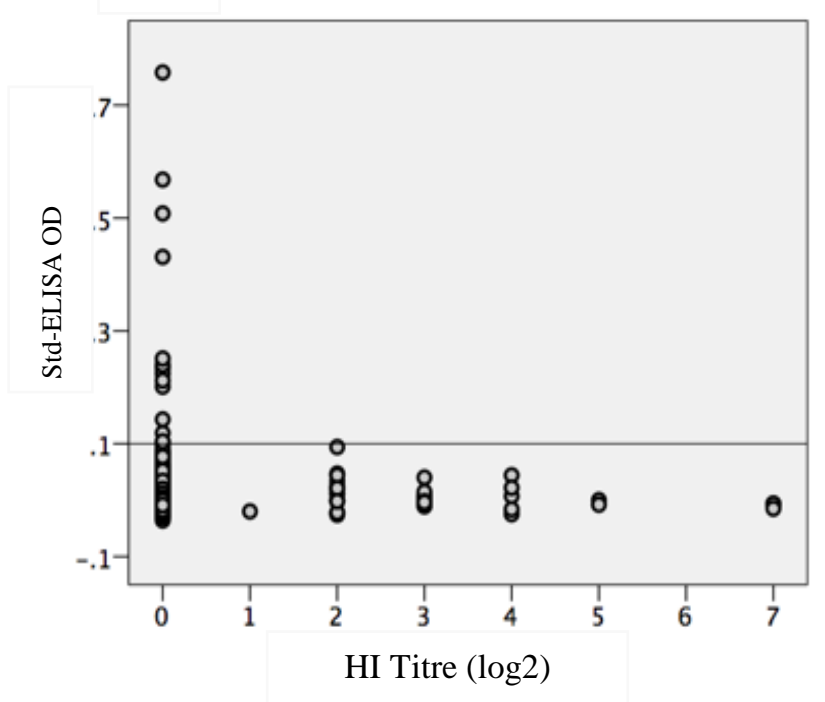

Figure 1. Agreement between the results of MM2e-ELISA with NP-ELISA (A) and MM2e ELISA with HI test (B) on 420 sera collected from native chicken that roamed nearby commercial layer farms

ELISA or HI test. However, no serum was positive in all three tests and, the number of sera that were positive with any two tests was very small (Table 2). Since the AAHL-NP ELISA detect antibody to NP protein, all sera from birds that had been infected by any influenza A viruses should have been positive in the test. All sera that were positive in HI test or M2e ELISA should also be positive in the NP ELISA. However, only 3/10 sera in this study that were positive in HI test were also positive in AAHL-NP ELISA.

The seropositivity with the AAHL-NP ELISA and $\mathrm{HI}$ test could not have been due to vaccination, because no vaccination against $\mathrm{AI}$ had been carried out in those villages for the last three years. Unlike the NP ELISA and HI test, M2e ELISA detect M2e antibody that is induced only by infection with influenza virus. There were 14 sera $(3.3 \%)$ positive for M2e antibodies. Four sera had OD of $>0.1-0.2$, six had OD of $>0.2-0.3$ three had OD of $>0.3-0.5$, and one serum had high (>0.7) OD. There was only one of the M2e-positive serum that was positive in NP ELISA, and none were positive for HI test (Table 1, Figure 1).

The M2e-positive sera were not clustered in any of the villages or around a particular layer farm (Figure 2). The percentage of M2e positive sera in mature chickens was twice as high as that in young chickens (results not shown).

\section{Recombinant-NP-based assays}

Examination of sera that were positive in either HI test, AAHL-NP and MM2e ELISAs revealed that all of those positive in AAHL-NP ELISA were also positive in the indirect NP ELISA. Two AAHL-NP-ELISApositive sera with high OD (0.788 and 0.956) in indirect NP ELISA were negative in M2e ELISA (standardized 
M2e-ELISA ODs $=-0.016$ and -0.015 ) (Table 3). Examination of the NP-ELISA-positive sera with immunoblotting indicated that the majority of sera (7/10) recognized the recombinant nucleoprotein. One sample (bird\# 365), however, reacted unexpectedly because despite being positive in both AAHL- and direct-NP ELISAs the serum did not recognized the NP protein (Table 3, Figure 3A).

\section{Recombinant-H5-based assays}

Results of indirect-H5 ELISA on serially diluted sera are presented in Figure 4. All sera that were negative in HI test, M2e and AAHL-NP ELISAs were also negative in the indirect-H5 ELISA. One serum (from bird\# 450) that had a HI titre of $7 \log 2$ had a high OD even after the serum was diluted at 1:3200. The other serum with $\log 2 \mathrm{Hi}$ titre of 4 (from bird \#365) had a much lower OD at any serum dilution. All sera that were negative in $\mathrm{HI}$ test were also negative in direct $\mathrm{H} 5$ ELISA.
The result of the indirect-H5 ELISA was in agreement with that of the immunoblot, as all sera with standardised OD ELISA's of $\geq 0.048$ were positive whereas those of $\leq-0.041$ were negative in the immunoblot (Table 2, Figure 3B). However, the antibody titres as determined by $\mathrm{HI}$ test were poorly correlated with the ELISA's OD and the immunoblot signal. For example, sera \# 261 and \# 262 that both had HI titre of $7 \log 2$, and sera \# 231 with $5 \log 2$ were all negative in the ELISA and immunoblot. Whereas, sera \# 358 and \#453 that both were negative in HI test were positive in both the ELISA and immunoblot (Table 2, Figure 3B).

Regardless of the inconsistency of the results given by different tests on many sera, there were at least two sera that the test results were consistent. The results of all tests on serum from bird\# 450, except MM2e ELISA, were all strongly positive. The results of tests on serum from bird \# 365 were comparable with those on serum from bird\# 450, except that the serum failed to recognize the NP in immunoblot (Table 2, Figure 3B).

Table 2. Results of the examination of sera from native chicken with NP ELISA, MM2e ELISA and HI test

\begin{tabular}{|c|c|c|c|c|c|c|c|}
\hline Bird \# & $\begin{array}{c}\text { M2e } \\
\text { ELISA's } \\
\text { OD }\end{array}$ & $\begin{array}{l}\text { AAHL-NP } \\
\text { ELISA }\end{array}$ & $\begin{array}{l}\text { Direct-rec-NP } \\
\text { ELISA's OD }\end{array}$ & W'blot-rec NP & $\begin{array}{l}\text { HI- titre } \\
(\log 2)\end{array}$ & $\begin{array}{l}\text { Direct-rec- H5 } \\
\text { ELISA's OD }\end{array}$ & $\begin{array}{c}\text { W'blot rec } \\
\text { H5 }\end{array}$ \\
\hline 358 & 0.568 & - & -0.041 & + & 0 & 0.079 & + \\
\hline 380 & 0.508 & - & 0.001 & + & 0 & -0.091 & - \\
\hline 453 & 0.251 & - & 0.027 & + & 0 & 0.048 & + \\
\hline 343 & 0.094 & - & -0.009 & - & 0 & -0.041 & - \\
\hline 231 & 0.000 & - & -0.054 & + & 5 & -0.050 & - \\
\hline 261 & -0.006 & - & -0.038 & + & 7 & -0.048 & - \\
\hline 262 & -0.007 & + & -0.066 & + & 7 & -0.068 & - \\
\hline 297 & -0.008 & - & 0.048 & - & 5 & 0.324 & + \\
\hline 450 & -0.015 & + & 0.956 & + & 7 & 0.991 & + \\
\hline 365 & -0.016 & + & 0.788 & - & 4 & 0.948 & + \\
\hline
\end{tabular}


Tarigan et al. Circulating H5N1 virus among native chicken living around commercial layer farms
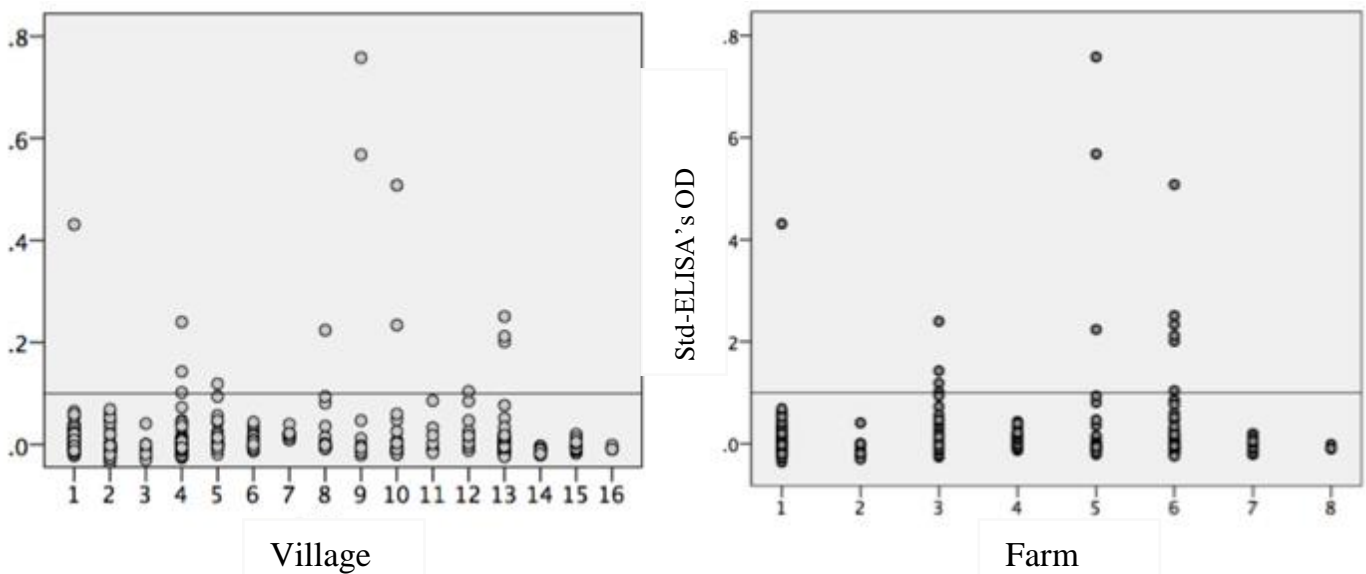

Figure 2. The NP-ELISA positive samples were spread randomly within the village (A) or around the layer farms (B). Note: the identities for the farms and villages are presented in table 1

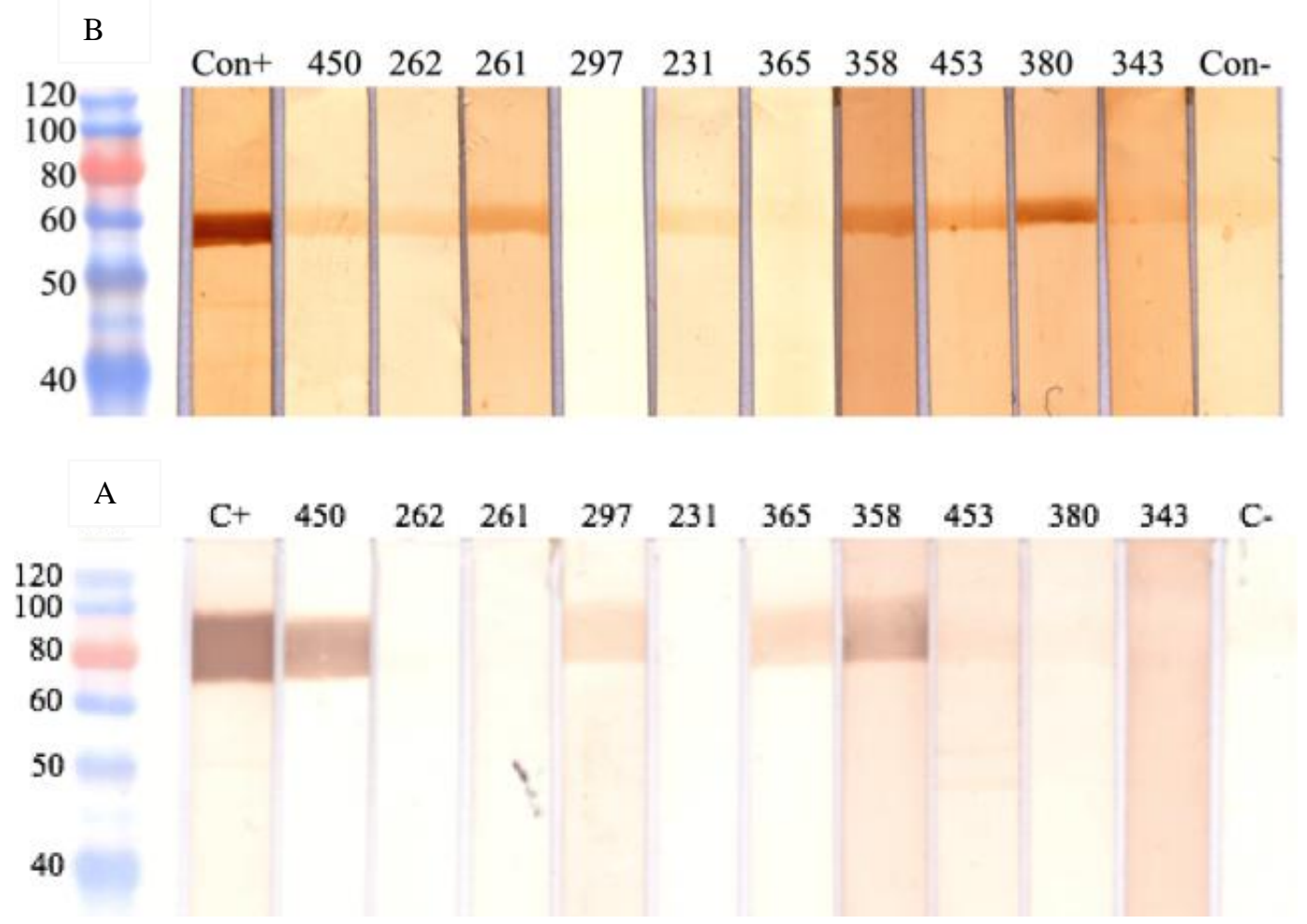

Figure 3. Recognition of nucleoprotein (A) and hemagglutinin H5 (B) by sera from native chicken that are seropositive in HI test, NP and M2e ELISAs 


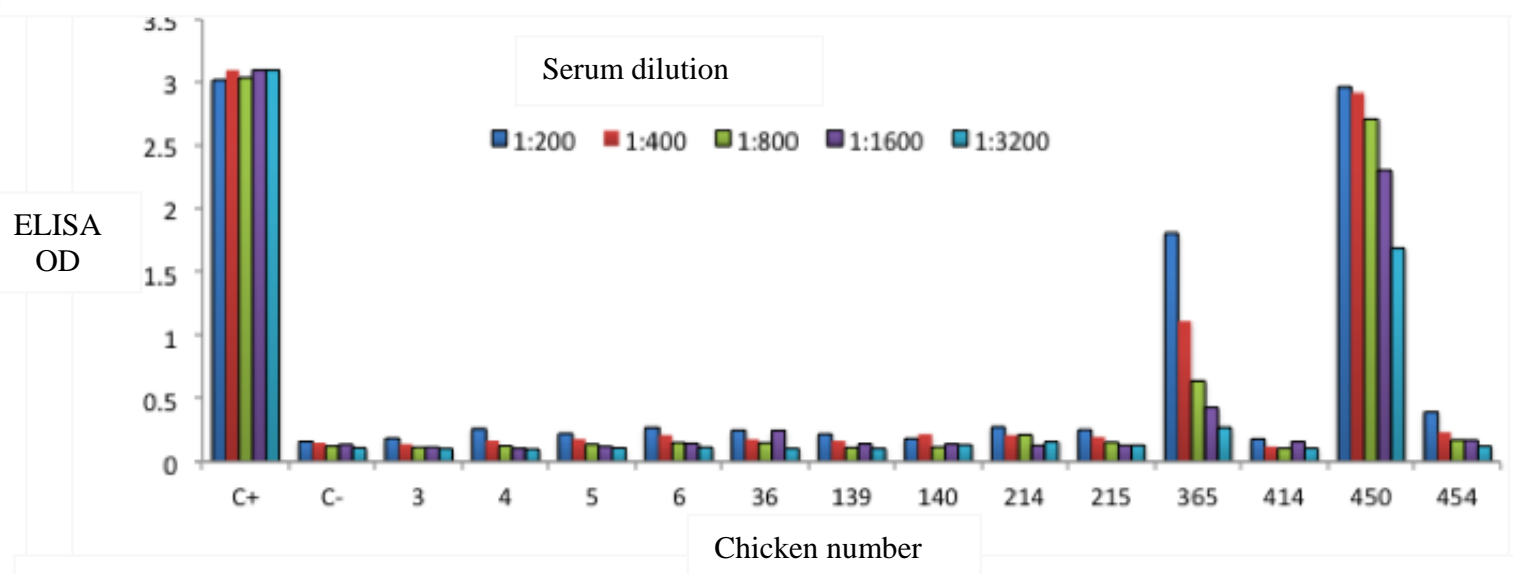

Figure 4. Direct-H5 ELISA on titrated sera from native chicken. Sera \# 3, 4, 5, 6, 36, 139,140, 214 and 215 were negative on HI test, M2e ELISA and AAHL-NP ELISA, serum \#414 was positive M2e (OD=0.201), serum\# 454 was positive AAHL-NP ELISA, sera \# 365 and 450 see table 2 . C + serum from chicken that had been 2 times vaccinated follow by infection with $\mathrm{H} 5 \mathrm{~N} 1, \mathrm{C}$ - serum from bird naïve to H5N1

\section{Discussion}

This study provides serological evidence of the circulating H5N1 virus among native chicken living around commercial layer farms. As shown in this study, $8.6 \%$ of the native chickens were seropositive to AI virus based on one or more serological tests. Despite the difficulty in interpretation of the test results on many positive sera because different tests did not support one another, seropositivity in at least two birds has most likely resulted from infection by subtype H5 influenza virus. This is because sera from birds contained antibodies to the NP as indicated by high OD in indirect ELISA, strong inhibition in competitive ELISA and reaction to the recombinant NP in immunoblot assay. Antibody to HA5 was evidenced by high HI titres and high OD in indirect H5 ELISA and strong reaction to the recombinant $\mathrm{H} 5$ in immunoblot assay. Since H5 subtypes, other than H5N1, have been unknown in Indonesia, and the H5N1 subtype has been endemic in this country since 2003, the seropositivity in those birds is likely to be caused by H5N1 virus subtype.

The fact that H5N1-seropositive chickens were found in native chickens living around commercial layer farm has at least two important implications. Firstly, layer farms may be under threat from H5N1 virus challenge originating from their immediate surroundings. The absence of the disease in commercial farms for the last several years may be attributed to the effectiveness of biosecurity measures applied and vaccination. Secondly, seroconversion to H5N1 virus in those birds, without being preceded by apparent mortality or clinical disease, in the population of the native chicken suggest that the pathogenic trait of the H5N1 virus may have waned considerably. Although low pathogenic $\mathrm{H} 5 \mathrm{~N} 1$ exists in nature, its existence in poultry is uncommon (Duan et al. 2007; Pei et al. 2009; Kim et al. 2011; Van Borm et al. 2011; Ping et al. 2012). In H5N2 subtype, mutation of LPAI into HPAI and existence of both LPAI and HPAI in the same poultry farms have been well characterized in poultry in USA (Swayne 2008). As far as we are aware similar incidences of H5N1 subtype have not been found. It is true that the HPAI H5N1 is believe to mutate from a LPAI but where and when the mutation took place and which H5N1 LPAI as the progenitor of the H5N1 HPAI are unknown (Wan 2012).

The notion that the circulating HPAI H5N1 strains have waned in pathogenicity supported by the reduction in the number of reported outbreak of $\mathrm{AI}$ in native chickens in Indonesia. The decline of the H5N1 cases was not caused by any control measures applied. There are no control measures that had been applied in native chickens attributed to declining of the H5N1 outbreak. At the peak of H5N1 outbreak, mass vaccination in sector-4 poultry had been attempted but discontinued as it was not feasible (Siregar et al. 2007). Application of biosecurity in backyard poultry to an extent effective to abate the H5N1 infection is difficult to achieve (Conan et al. 2012).

Until December 2008, Sukabumi and Cianjur were the districts with the highest cases of $\mathrm{H} 5 \mathrm{~N} 1$ in West Java, and West Java was the province with the highest number of H5N1 outbreaks in Indonesia (Yupiana et al. 2010). However, since 2009 outbreaks of AI in chicken in those districts have been rarely reported and occurrence of $\mathrm{H} 5 \mathrm{~N} 1$ outbreak in the whole country has dropped significantly (www.keswan.ditjennak. pertanian.go.id.). The increase in the number of $\mathrm{H} 5 \mathrm{~N} 1$ outbreaks since 2012 in Indonesia is related to the 
spread of the new H5N1 clade, clade 2.3.2.1, (Dharmayanti et al. 2014). However, this new clade H5N1 caused disease and mortalities mostly in ducks, whereas poultry including, native chicken, apparently were not affected (Empres 2014).

The discrepancy of results given by different tests on the same sera were unexpected because all tests used in this study had been validated before use. The AAHLnucleoprotein ELISA is a competitive ELISA that had been proved to be sensitive and specific for detection of antibody to the NP of type-A influenza viruses in birds and mammals (Sergeant et al. 2009; Sergeev et al. 2013) and was used in the surveillance of AI in wild and domesticated birds in Australia (OCVO 2010).

The MM2e ELISA was shown to be highly specific based on a validation study using chicken serum samples from vaccination and challenge trials (Tarigan et al. 2015). Since not all birds infected with the influenza virus seroconvert to M2e, the percentage of native chicken that had been infected by influenza virus must therefore been higher than the M2e seroprevalence of 3.3\% (Lambrecht et al. 2007; Kim et al. 2010; Hemmatzadeh et al. 2013; Tarigan et al. 2015).

The result of $\mathrm{HI}$ test in this study were more incongruent in comparison to other tests. For example, two sera with high $(7 \log 2) \mathrm{HI}$ titres were negative in the indirect ELISA and immunoblot using recombinant H5 encoded by gene derived from an Indonesian isolate. The HI test in this study was performed in a nationally accredited diagnostic laboratory that routinely performs $\mathrm{HI}$ testing.

The cause of the incongruity of the results provided by the well-validated $\mathrm{HI}$ test, nucleoprotein and MM2e ELISA is unknown. The incongruent results caused difficulty in determining the seroprevalence of AI in the native chicken. A more sensitive and specific test is needed for native chicken. As far as we are aware, similar problem has not been reported. This is probably because most serological studies usually use only one test, either HI test or ELISA (Nasreen et al. 2013; Chang et al. 2014). A possible reasons is that HI, MM2e ELISA and NP ELISA all measure different type of antibodies and it is likely that the duration of these antibodies in serum following infection also differ. The HI antibodies last long in vaccinated chickens (Meulemans et al. 1987) whereas the M2e antibodies last only about 8 weeks (Tarigan et al. 2015), whereas the duration of NP antibodies is unknown.

In summary this study shows that $\mathrm{H} 5 \mathrm{~N} 1$ virus influenza is still circulating among native chicken near commercial layer farms. Infection in these chickens is subclinical probably because the pathogenicity of the virus is waning. Since the commercial layer farms are still under threat, vaccination and strict biosecurity are still necessary. The results of $\mathrm{HI}$ test, NP and M2e ELISAs are not in agreement suggesting that a more sensitive and specific test is needed for surveillance of $\mathrm{AI}$ in native chicken.

\section{CONCLUSION}

To sum up, this study shows that H5N1 virus influenza is still circulating among native chicken near commercial layer farms. Infection in these chickens is subclinical probably because the pathogenicity of the virus is waning. Since the commercial layer farms are still under threat, vaccination and strict biosecurity are still necessary. The results of HI test, NP and M2e ELISAs are not in agreement suggesting that a more sensitive and specific test is needed for surveillance of $\mathrm{AI}$ in native chicken.

\section{ACKNOWLEDGMENT}

This work was supported by the Australian Centre for International Agricultural Research under Grant AH/2010/039. The authors thank Mrs Gita Sekarmila, Mr Achpas and the animal caretakers for their excellent technical assistance.

\section{REFERENCES}

Chang H, Dai F, Liu Z, Yuan F, Zhao S, Xiang X, Zou F, Zeng B, Fan Y, Duan G. 2014. Seroprevalence survey of avian influenza A (H5) in wild migratory birds in Yunnan Province, Southwestern China. Virol J. 11:18.

Conan A, Goutard FL, Sorn S, Vong S. 2012. Biosecurity measures for backyard poultry in developing countries: a systematic review. BMC Vet Res. 8:240.

Dharmayanti NLPI, Hartawan R, Pudjiatmoko, Wibawa H, Hardiman, Balish A, Donis R, Davis CT, Samaan G. 2014. Genetic characterization of clade 2.3.2.1 avian influenza $\mathrm{A}(\mathrm{H} 5 \mathrm{~N} 1)$ viruses, Indonesia, 2012. Emerg Infect Dis. 20:671-674.

Duan, Campitelli LL, Fan XH, Leung YH, Vijaykrishna D, Zhang JX, Donatelli I, Delogu M, Li K, Foni E, Chiapponi C, Wu WL, Kai H, Webster RG, Shortridge KF, Peiris JS, Smith GJ, Chen H, Guan Y. 2007. Characterization of low-pathogenic H5 subtype influenza viruses from Eurasia: implications for the origin of highly pathogenic $\mathrm{H} 5 \mathrm{~N} 1$ viruses. J Virol. 81:7529-7539.

Empres F. 2014. Update on the continuous spread and expansion of H5N1 highly pathogenic avian influenza Clade 2.3.2.1 in Asia (2010-2012). Focus on 7:1-12.

Hemmatzadeh F, Sumarningsih S, Tarigan S, Indriani R, Dharmayanti NLPI, Ebrahimie E, Igniatovic J. 2013. Recombinant M2e protein-based ELISA: a novel and inexpensive approach for differentiating avian influenza infected chickens from vaccinated ones. PLoS One. 8:e56801. 
Kim BS, Kang HM, Choi JG, Kim MC, Kim HR, Paek MR, Kwon JH, Lee YJ. 2011. Characterization of the lowpathogenic H5N1 avian influenza virus in South Korea. Poult Sci. 90:1449-1461.

Kim MC, Choi JG, Kwon JS, Kang HM, Paek MR, Jeong OM, Kwon JH, Lee YJ. 2010. Field application of the H9M2e enzyme-linked immunosorbent assay for differentiation of H9N2 avian influenza virus-infected chickens from vaccinated chickens. Clin Vaccine Immunol. 17:1977-1984.

Lambrecht B, Steensels M, Van Borm S, Meulemans G, van den Berg T. 2007. Development of an M2e-specific enzyme-linked immunosorbent assay for differentiating infected from vaccinated animals. Avian Dis. 51:221226.

Meulemans G, Carlier MC, Gonze M, Petit P. 1987. Comparison of Hemagglutination-Inhibition Agar Gel Precipitin, and Enzyme-Linked Immunosorbent Assay for Measuring Antibodies against Influenza Viruses in Chickens. Avian Dis. 31:560-563.

Nasreen S, Uddin Khan S, Azziz-Baumgartner E, Hancock K, Veguilla V, Wang D, Rahman M, Alamgir AS, SturmRamirez K, Gurley ES, Luby SP, Katz JM, Uyeki TM. 2013. Seroprevalence of Antibodies against Highly Pathogenic Avian Influenza A (H5N1) Virus among Poultry Workers in Bangladesh, 2009. PLoS One. 8:e73200.

[OCVO] Office of the Chief Veterinary Officer. 2010 National Avian Influenza Surveillance Dossier. Office of the Chief Veterinary Officer, Australian Government Department of Agriculture, Fisheries and Forestry, Canberra.

[OIE] Office International des Epizooties. 2014. Avian Influenza. In: Manual of Diagnostic tests and Vaccines for the Terrestrial Animals, Chapter 2.3.4. http://www.oie.int/international-standard-setting/ terrestrial-manual/access-online/.

Pei Y, Swinton J, Ojkic D, Sharif S. 2009. Genetic characterization of two low pathogenic avian influenza virus H5N1 isolates from Ontario, Canada. Virus Genes. 38:149-154.
Ping J, Selman M, Tyler S, Forbes N, Keleta K, Brown EG. 2012. Low-pathogenic avian influenza virus $\mathrm{A} /$ turkey/Ontario/6213/1966 (H5N1) is the progenitor of highly pathogenic A/turkey/Ontario/7732/1966 (H5N9). J Gen Virol. 93:1649-1657.

Sergeant ES, Kirkland PD, Cowled BD. 2009. Field evaluation of an equine influenza ELISA used in New South Wales during the 2007 Australian outbreak response. Prev Vet Med. 92:382-385.

Sergeev AA, et al. 2013. Infection of chickens caused by avian influenza virus $\mathrm{A} / \mathrm{H} 5 \mathrm{~N} 1$ delivered by aerosol and other routes. Transbound Emerg Dis. 60:159-165.

Siregar SE, Darminto, Weaver J, Bouma A. 2007. The vaccination programme in Indonesia. Dev Biol (Basel). 130:151-158.

Suarez DL. 2005. Overview of avian influenza DIVA test strategies. Biologicals. 33:221-226.

Swayne DE. 2008. High pathogenicity Avian Influenza in the Americas. In: Avian Influenza. Swayne DE, editor, Iowa (USA): Blackwell Publishing. p. 191-216.

Tarigan S, Indriani R, Durr PA, Ignjatovic J. 2015. Characterization of the $\mathrm{M} 2 \mathrm{e}$ antibody response following highly pathogenic $\mathrm{H} 5 \mathrm{~N} 1$ avian influenza virus infection and reliability of M2e ELISA for identifying infected among vaccinated chickens. Avian Pathol. 44:259-268.

Van Borm S, Vangeluwe D, Steensels M, Poncin O, van den Berg T, Lambrecht B. 2011. Genetic characterization of low pathogenic $\mathrm{H} 5 \mathrm{~N} 1$ and co-circulating avian influenza viruses in wild mallards (Anas platyrhynchos) in Belgium, 2008. Avian Pathol. 40:613-628.

Wan XF. 2012. Lessons from emergence of A/goose/Guangdong/1996-like H5N1 highly pathogenic avian influenza viruses and recent influenza surveillance efforts in southern China. Zoonoses Public Health. 59:32-42.

Yupiana Y, de Vlas SJ, Adnan NM, Richardus JH. 2010. Risk factors of poultry outbreaks and human cases of H5N1 avian influenza virus infection in West Java Province, Indonesia. Int J Infect Dis. 14:e800-805. 